\title{
Forest Ecosystem Services and Local Communities: Towards a Possible Solution to Reduce Forest Dependence in Bach Ma National Park, Vietnam
}

\author{
Nguyen Thi Hong ${ }^{1} \cdot$ Izuru Saizen ${ }^{1}$
}

Published online: 27 June 2019

(C) The Author(s) 2019

\begin{abstract}
Conservation of protected areas is likely to be challenging in the long term if the dependence of local communities on natural resources is not measured appropriately. We investigated forest ecosystem services utilized by communities living around the Bach Ma National Park, Vietnam, and examined their spatial distributions through the integration of data from interviews, participatory mapping, and GIS analysis. The results suggest that provisioning services are crucial to the local livelihoods, and especially for an ethnic minority group. Many respondents confirmed the collection of specific types of forest foods, materials, and water resources mainly used for family consumption. We conducted spatial pattern analysis with land use, administrative units, terrain conditions, and accessibility, and clarified the characteristics of the spatial distribution of ecosystem service collection in relation to these factors, resource abundance, and forest governance. We propose the introduction of community-based tourism as one means to improve the livelihood opportunities of the ethnic minority groups to reduce their forest dependence.
\end{abstract}

Keywords Ecosystem services $\cdot$ Forest resources dependence $\cdot$ Local livelihoods $\cdot$ Forest ecosystem management $\cdot$ Protected areas $\cdot$ Bach Ma National Park $\cdot$ Vietnam

\section{Introduction}

The concept of ecosystem services gained general recognition following the publication of the Millennium Ecosystem Assessment, which established four categories of ecosystem services: provisioning, supporting, regulating, and cultural (Alcamo 2003). It has been shown that forests provide several significant ecosystem services that contribute to human wellbeing (Lakerveld et al. 2015). Several studies have indicated that economically challenged rural communities living near forests significantly depend on them for provision of ecosystem services for their livelihood as well as for resources, such as food, fiber, and firewood (Alcamo 2003; Vihervaara et al. 2012; Langat et al. 2016). However, it is also widely recognized that intensive dependence on forest resources causes degradation that may lead to reduction in the provisioning

Nguyen Thi Hong

nguyen.thi.82u@st.kyoto-u.ac.jp; hongmoitruong@gmail.com

1 Laboratory of Regional Planning, Graduate School of Global Environmental Studies, Kyoto University, Research Building-5, Yoshida-Honmachi, Sakyo-ku, Kyoto 606-8501, Japan services and impede poverty reduction efforts. In particular, unsustainable utilization of ecosystem services by local communities, especially from protected areas and their buffer zones, may lead to ecological problems such as ecological fragmentation (Struhsaker et al. 2005). In addition, conservation strategies for protected areas are unlikely to be successful in the long run if the needs of the local communities with regard to natural resources are not quantified and subsequently incorporated in relevant policies (McNeely 1994; Palomo et al. 2013).

Vietnam has 164 terrestrial protected areas covering 7.4\% of the country's total land area (De Queiroz et al. 2013) located in special-use forests managed by fine and fence policy (Decree No. 117, 2010). However, the forest biodiversity has been declining (Pilgrim and Tu 2007). Vietnam has been identified as having a high number of threatened species (Pilgrim and Tu 2007): The International Union for Conservation of Nature assessed 3990 species and found that $512(13 \%)$ were threatened with the extinction (De Queiroz et al. 2013). Of these, 152 are found in forests, 110 in inland wetlands, and 52 in near shore waters (De Queiroz et al. 2013). The factors driving forest biodiversity loss in Vietnam are excessive harvest of timber and non-timber forest products, land use changes, and the lack of a sustainable 
management mechanism (De Queiroz et al. 2013). This can be attributed to the poor socioeconomic conditions of local communities in the buffer zones. These communities of impoverished, near-subsistence farmers dependent on small paddy landholdings lack the capacity to produce food in sufficient quantities and, consequently, tend to rely on forest ecosystem services (Gilmour and Nguyen 1999; De Queiroz et al. 2013). Few studies have attempted to establish empirical data for the forest dependence of local communities living near the protected areas. A detailed understanding of the dependence is likely to be key to successful forest management.

In this study, we posit that explicit data on ecosystem services utilized by the local communities are useful for developing appropriate forest management and restoration strategies. In this context, we attempted to identify the specific ecosystem services utilized, their harvest seasons, and usage and clusters of collection through interviews. Furthermore, participatory mapping was carried out to obtain knowledge, perspectives, and needs of local people relying on ecosystem services that can be integrated into scientific research programs to develop sustainable management strategies (Brown 2004; Bryan et al. 2010; Ramirez-Gomez et al. 2015; Delgado-Aguilar et al. 2017).

Our specific objectives in this study were: (1) to identify the forest ecosystem services collected by local communities and map the frequency of collection to provide a better understanding of the demand for forest ecosystem services, and (2) to identify possible strategies to reduce the forest dependence.

\section{Study Area}

This study was conducted in 24 villages in the buffer zones of Bach Ma National Park, Vietnam (Fig. 1). The park is designated as a protected area and was established in 1991 to conserve the only green transect left in Vietnam, which stretches from the South China Sea to the border with Laos (Tran and Ziegler 2001). The park is located in central Vietnam and covers a total area of about 37,487 ha $(34,380$ ha in Thua Thien Hue province and 3107 ha in Quang Nam province) with three subdivisions: the strictly protected area (12,065 ha), the ecological restoration area (20,234 ha), and the administrative service area (5188 ha). The common types of forest ecosystem are tropical monsoon forests at lowland areas and subtropical monsoon forests at altitudes between $900 \mathrm{~m}$ and $1450 \mathrm{~m}$ (Tran and Ziegler 2001). Although significant percentages of species in Vietnam were identified in this area (7\% and $17 \%$ of all fauna and flora, respectively) (Phan 2015), the park has faced many threats leading to biodiversity loss and forest degradation (Plant 2002; Webb and Honda 2007; Spelchan et al. 2011; Huynh et al. 2016).

The buffer zones are located within 15 communes across three districts in two provinces and cover an area of 58,676 ha. Thua Thien Hue province contains two districts, i.e., Nam Dong (mountainous district) and Phu Loc (plain district), while Quang Nam province contains one mountainous district (Dong Giang). Four ethnic groups inhabit the region: the Kinh constitute $84.13 \%$ of the population, the Cotu $15.15 \%$, the Van Kieu $0.68 \%$, and the Muong $0.04 \%$ (Van et al. 2016). While most Kinh live in the plain district, most ethnic minorities inhabit the mountainous districts. A population of 79,000 distributed over 25,257 households live in the buffer zone and the average population density is 159 people $/ \mathrm{km}^{2}$ and the highest and lowest are 790 and 10 people $/ \mathrm{km}^{2}$, respectively (Van et al. 2016). Ten out of 15 communes have been classified as poor socioeconomic units by the government (Decision No. 73, 2016).

The dominant land uses in the study area are forests and farmland. Forestland is divided into three types (Fig. 3). First, special-use forests have been largely designated for (1) the conservation of nature and forest genetic sources, (2) scientific research, (3) protection of historical and cultural relics and landscapes, and (4) services of recreation and tourism in

Fig. 1 Study area showing the location of target villages

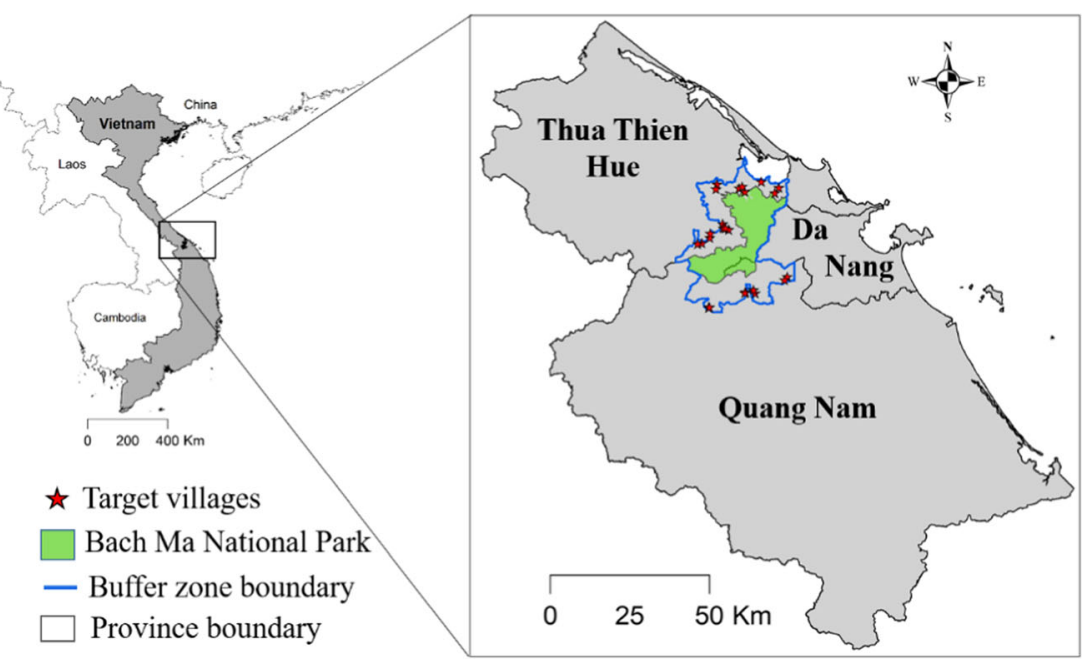


combination with protection and contribution to environmental protection (Decree No. 117, 2010). The entire Bach Ma National Park is designated as a special-use forest. Second, protection forests are designed to (1) protect soils and water sources, (2) prevent erosion and desertification, and (3) restrict natural calamities and regulate climate (Decision No. 17, 2015). Finally, production forests are allocated for producing and trading of timber and non-timber forest products in combination with contributing to environmental protection (Decision No. 49, 2016).

\section{Methodology}

We used a combination of qualitative social science methods, such as interviews and participatory mapping as well as quantitative spatial analyses in this study.

Interview surveys were conducted from April to June 2017. Interviews were based on semi-structured questionnaires and were initially conducted with 20 respondents to identify crucial forest ecosystem services for the local communities. Interviewees were experts and local officials working in government or non-governmental organizations and were familiar with the natural resources existing in the area as well as the livelihood practices of local communities. Based on consultation with commune officials, 24 villages that consist of the highest number of poor households living near the forest were selected as target villages and the different provisioning ecosystem services for interviews with the local communities were identified. Twenty-four meetings with 170 participants, including local community representatives, were undertaken to elucidate the crucial ecosystem services. The participants in meetings were selected based on the results of interviews with village leaders. Generally, the men access the forests to collect forest provisioning ecosystem services, occasionally staying for several days to collect the varieties and amounts they need. The role of women was rarely mentioned. In several villages, they collected only foods (vegetables and mushrooms), but their main responsibilities were cited as housework, children, and cultivating agricultural crops. Structured questionnaires were employed to obtain information regarding (1) socio-demographic aspects of respondents, (2) ecosystem services collected by the local communities, (3) harvest seasons and usages of ecosystem services, and (4) collection locations. The questions followed a simple and straightforward design, e.g., "where do you often get forest food?" because the local community members were not familiar with the concept of ecosystem services.

A base map and colored beans were used for the participatory mapping exercise (Fig. 2). The participants were asked to indicate the locations of collected ecosystem services by putting colored beans on the base map. This mapped information was subsequently digitized using ArcGIS 10.5; the group layers for foods, materials, and water resources were created by merging the separate layers followed by calculation of their densities. Vegetables, bamboo shoots, fruit, mushroom, fish, honey, and wild animal layers were merged into the food layer. Firewood, roof covering material, wood, rattan, medicinal plants, broom materials, and traditional Vietnamese hat material were merged into the material layer. The spatial characteristics of collection points and frequency levels of collection were considered in relation to land use, administrative units, terrain conditions, the proximity to village centers and main roads (Fig. 3), resource abundance, and forest governance.

\section{Results and Discussion}

\section{Socio-Demographic Characteristics of Participants in the Community Meetings}

The participants consisted of $97.6 \%(n=166)$ males and $2.4 \%$ $(n=4)$ females (Table 1). Previous studies have indicated that males play a greater role in collecting forest products (Shackleton et al. 2001; Sunderland et al. 2014). In our study
Fig. 2 Mapping the ecosystem services by local communities

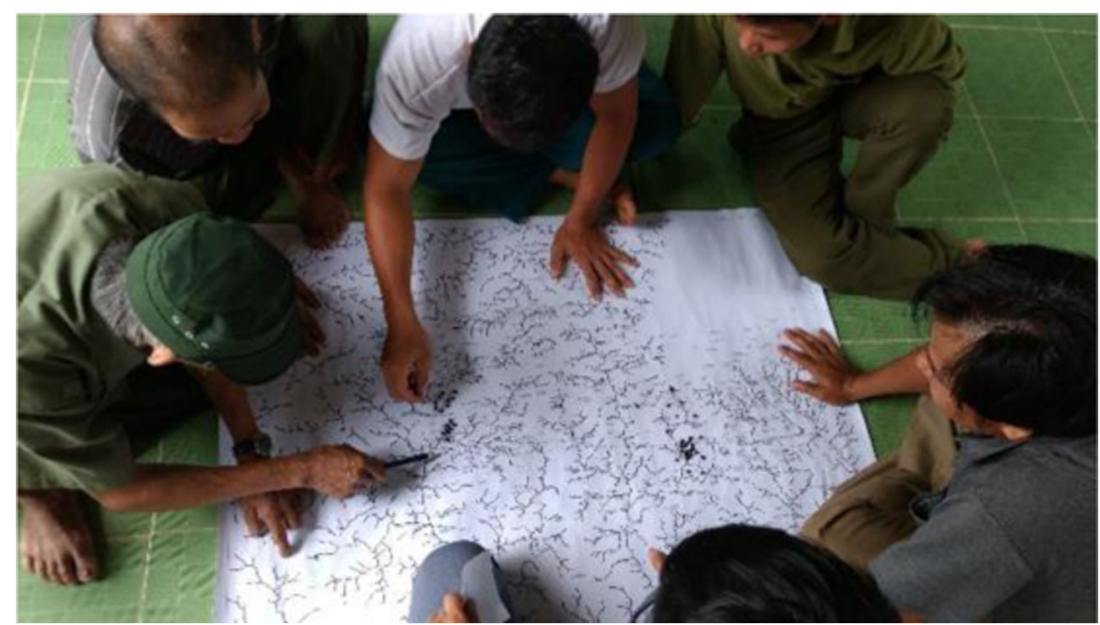



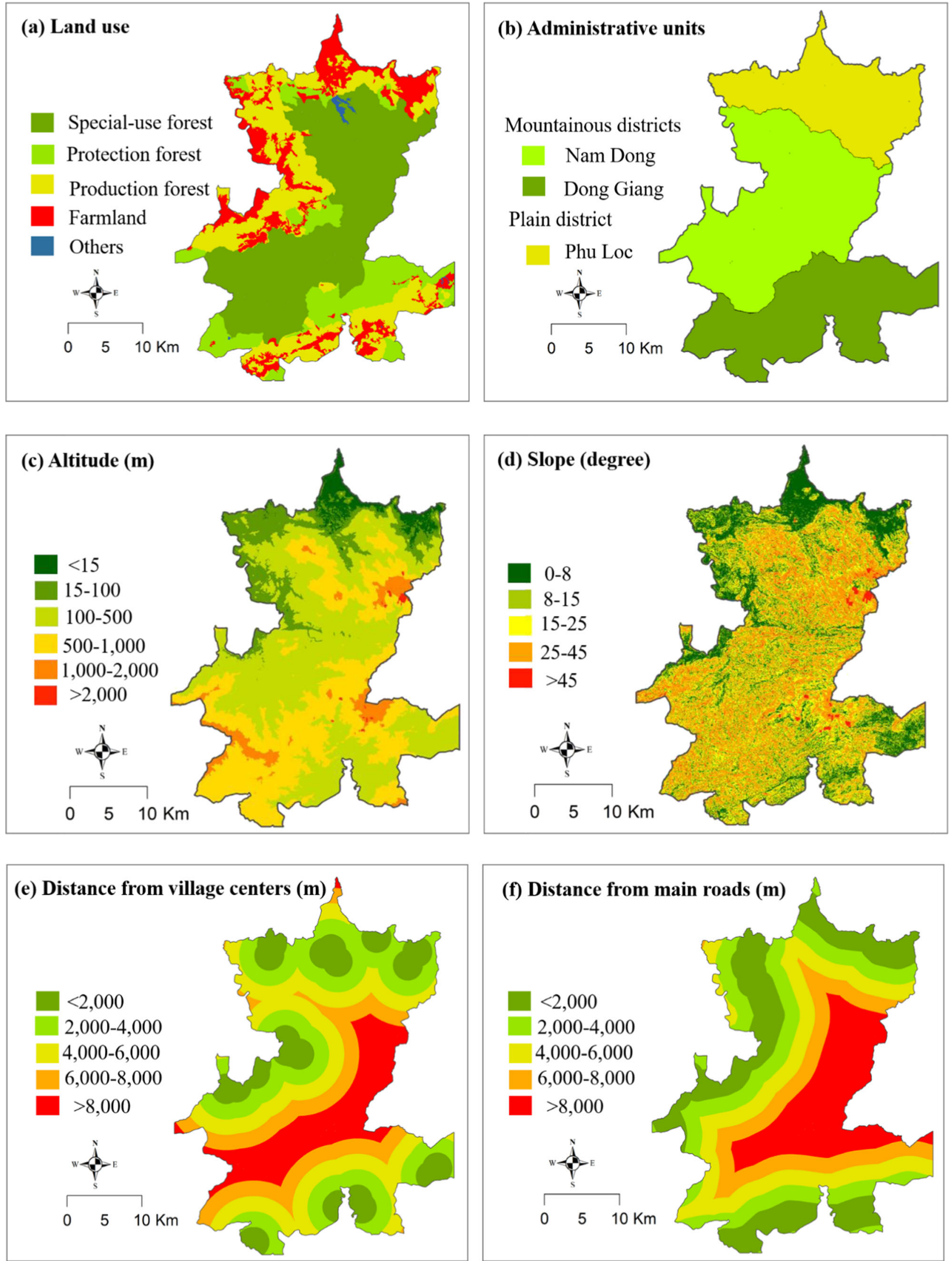

(f) Distance from main roads (m)

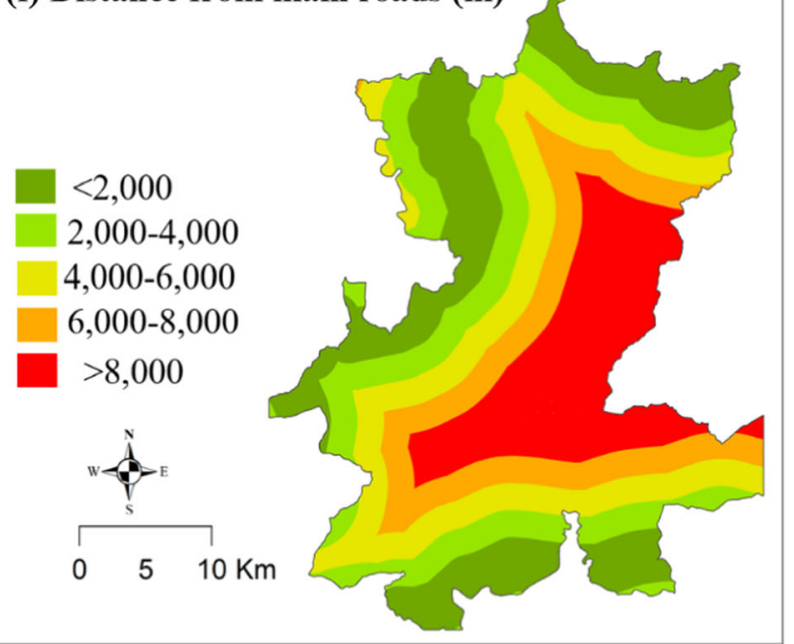

Fig. 3 Maps of factors considered in relation to the spatial distributions of ecosystem service collection 
Table 1 Socio-demographic characteristics of the participants in community participatory

\begin{tabular}{ll}
\hline Socio-demographic characteristics & $\begin{array}{l}\text { Percentages of participants } \\
(\%)(n=170)\end{array}$ \\
\hline Gender & 97.6 \\
Male & 2.4 \\
Female & \\
Age group (years) & 21.1 \\
18-37 & 65.9 \\
$38-49$ & 11.8 \\
$50-59$ & 1.2 \\
Over 60 & \\
Ethnicity & 31.8 \\
Main group (Kinh) & 68.2 \\
Ethnic minority & 4.1 \\
Muong & 64.1 \\
Cotu & \\
Occupation & 82.4 \\
Farmer & 15.3 \\
Village official & 2.3 \\
Housewives & \\
Origin of resident & 96 \\
Indigenous & 4 \\
Immigrant & \\
\hline
\end{tabular}

males were reported as also hunting, logging, and harvesting of other high-value forest products. Most participants $(65.9 \%$, $n=112$ ) were aged between 38 and 49 years, followed by 18 37 years $(21.1 \%, n=36)$, and $50-59$ years $(11.8 \%, n=20)$. Participants over 60 years constituted a small fraction $(1.2 \%$, $\mathrm{n}=2$ ). Mamo et al. (2007) and Coulibaly-Lingani et al. (2009) indicated that young people tend to collect forest products more than elderly people, however, in our study we found an opposite trend when comparing the age groups of 3849 years and 18-37 years. This is likely because the $38-$ 49 years age group had fewer choices for temporary alternative occupations in comparison to the younger age group.

Table 2 Forest ecosystem services mentioned by experts and local officials

\begin{tabular}{ll}
\hline Ecosystem services & $\begin{array}{l}\text { Numbers of experts and } \\
\text { local officials }(n=20)\end{array}$ \\
\hline Environmental education & 1 \\
Fiber & 1 \\
Tourism & 5 \\
Seeds and animal breeding & 6 \\
Aesthetics & 12 \\
Materials & 14 \\
Food & 20 \\
Water resources & 20 \\
\hline
\end{tabular}

Additionally, two ethnic minority groups, i.e., the Cotu and the Muong, accounted for $64.1 \%(n=109)$ and $4.1 \%(n=7)$ respectively of all participants when compared to the Kinh (the largest main ethnic group in Vietnam) who constituted $31.8 \%(n=54)$. The ethnic minorities have been classified as at or below the Vietnam poverty line for many generations (Decision No. 447, 2013, Decision No. 601, 2015; Decision No. 73, 2016), while the Kinh are more wealthy and have several livelihood options such as agriculture, aquaculture, and forestry. With regard to occupation, most participants were farmers $(82.4 \%, n=140)$, followed by village officials $15.3 \%(n=26)$, and housewives $(2.4 \%, n=4)$. Indigenous people constituted $96 \%(n=163)$ of the population while immigrant populations constituted $(4 \%, n=7)$.

\section{Collection of Forest Ecosystem Services}

The experts and local officials mentioned eight major ecosystem services that could be divided into provisioning and cultural ecosystem services in accordance with the Millennium Ecosystem Assessment report (Alcamo 2003) (Table 2). More than half of the interviewees considered provisioning ecosystem services, such as food, water resources, and materials, to be more important to the communities than cultural services. This finding is similar to previous studies, which have indicated that the dependence on provisioning ecosystem services

Table 3 Forest ecosystem services mentioned by participants in the meetings

\begin{tabular}{llll}
\hline Ecosystem services & The number of meetings $(n=24)$ & \\
\cline { 2 - 4 } & $\begin{array}{l}\text { Ethnic minority } \\
\text { participants }(\mathrm{n}=17)\end{array}$ & $\begin{array}{l}\text { Kinh participants } \\
(\mathrm{n}=7)\end{array}$ & Total \\
\hline Foods & & & \\
Wild animals & 12 & 3 & 15 \\
Honey & 15 & 1 & 16 \\
Fruit & 14 & 4 & 18 \\
Vegetables & 14 & 4 & 18 \\
Mushroom & 14 & 4 & 18 \\
Bamboo shoots & 14 & 5 & 19 \\
Fish & 15 & 6 & 21 \\
Materials & & & 8 \\
Vietnam traditional & 8 & 0 & 10 \\
$\quad$ hat materials & & 3 & 12 \\
Medicinal plants & 7 & 0 & 12 \\
Roof covering & 12 & 2 & 14 \\
$\quad$ materials & & 2 & 18 \\
Rattan & 10 & 4 & 22 \\
Broom materials & 12 & 7 & \\
Wood & 14 & 2 & \\
Firewood & 15 & & \\
Water resources & 14 & & \\
\hline
\end{tabular}


was more popular than cultural, regulating, and supporting services (López-Feldman and Wilen 2008; Sakai et al. 2016).

Overall, forest foods were mentioned more frequently than materials and water resources, and the ethnic minority groups collected many more kinds of ecosystem services than the Kinh (Table 3). Among forest foods, fish was most commonly mentioned $(n=21)$, followed by bamboo shoots $(n=19)$, fruit $(n=$ $18)$, vegetables $(\mathrm{n}=18)$, mushroom $(\mathrm{n}=18)$, honey $(n=16)$, and wild animals $(n=15)$. There were significant differences among forest materials. Firewood was most frequently mentioned ( $n=$ $22)$, followed by wood $(\mathrm{n}=18)$, broom materials $(n=14)$, rattan $(n=12)$, roof covering materials $(\mathrm{n}=12)$, and medicinal plants $(n=10)$. In addition, natural springs were the main source of water supply to the villages and were mentioned by the ethnic minorities in 14 meetings and by Kinh in two meetings.

Previous studies have shown that most local communities living in or near forests in developing countries are poor and rely heavily on natural resources for their subsistence (Mamo et al. 2007; van Noordwijk 2017). Our results in this study show that the number and type of ecosystem services increased in proportion to the number of ethnic minority participants in the meetings. At seven of eight meetings in Dong Giang district, the Cotu participants emphasized that their food requirements were largely met by forest ecosystem services and the agricultural products. However, in meetings organized in Phu Loc district where the Kinh people were the majority of participants, forest foods were not mentioned as the main source of supply. In addition, firewood was the most frequently mentioned material in meetings organized in the two mountainous districts. This is consistent with Kim et al.'s (2017) conclusion that firewood is main energy source in rural families in Vietnam. Moreover, Ramage et al. (2017) highlighted that the demand for wood for the construction of houses is one of the major forest dependences globally, especially among poor communities. Our results reflect this as at $75 \%$ of the meetings $(n=18)$ participants indicated dependence in this regard.

The overall responses to harvest seasons of collected ecosystem services were not significantly different among the meetings (Table 4). Most foods, except mushrooms and honey, could be collected year-round. Water resources were available year-round; however, participants frequently mentioned some water quality problems, such as bad smell and muddy color. Eighty percent or more of collected foods, except honey and bamboo shoots, were collected for family consumption; $88 \%$ of honey was sold to local markets or traders, and bamboo shoots were used for both the family consumption and sale (Table 5). Harvest of materials was conducted mainly during the summer months of July and August that are marked by little rain and highest monthly temperatures that facilitate collection and preliminary processing (Table 4). Movement in mountainous terrain during rainy season is challenging and most forest materials have to be dried before consumption or sale. Sixty percent or more of the collected materials, except rattan and traditional

Table 4 Harvest seasons of forest ecosystem services

\begin{tabular}{|c|c|c|c|c|c|c|c|c|c|c|c|c|}
\hline \multirow[t]{2}{*}{ Ecosystem services } & \multicolumn{12}{|c|}{ Month } \\
\hline & Jan & Feb & Mar & Apr & May & Jun & Jul & Aug & Sept & Oct & Nov & Dec \\
\hline \multicolumn{13}{|l|}{ Food } \\
\hline Wild animals & + & + & + & + & + & + & + & + & + & + & + & + \\
\hline Honey & & & ++ & ++ & ++ & ++ & ++ & & & & & \\
\hline Fruit & + & + & ++ & ++ & ++ & ++ & ++ & + & + & + & + & ++ \\
\hline Vegetables & ++ & ++ & ++ & ++ & ++ & ++ & ++ & + & + & + & + & ++ \\
\hline Mushroom & & & & & & & & & & ++ & ++ & ++ \\
\hline Bamboo shoots & + & ++ & ++ & ++ & ++ & ++ & ++ & + & + & + & + & + \\
\hline Fish & + & + & ++ & ++ & ++ & ++ & ++ & ++ & + & + & + & + \\
\hline \multicolumn{13}{|l|}{ Materials } \\
\hline Vietnam traditional hat materials & & & & + & + & + & ++ & ++ & & & & \\
\hline Medicinal plants & + & + & ++ & ++ & ++ & ++ & ++ & ++ & ++ & + & + & + \\
\hline Roof covering materials & & & & & & & ++ & ++ & & & & \\
\hline Rattan & & & + & + & + & ++ & ++ & ++ & & & & \\
\hline Broom materials & & & & + & + & + & ++ & ++ & & & & \\
\hline Wood & & & & & & & ++ & ++ & & & & \\
\hline Firewood & & + & + & + & + & ++ & ++ & ++ & & & & \\
\hline Water resources & ++ & ++ & ++ & ++ & ++ & ++ & ++ & ++ & ++ & ++ & ++ & ++ \\
\hline
\end{tabular}

The assessment was derived from the most frequent opinions of participants in the meetings

"++" refers to the main harvest season and "+" refers to the extra harvest season 
Table 5 Utilization of collected ecosystem services

\begin{tabular}{llll}
\hline Ecosystem services & $\begin{array}{l}\text { Family } \\
\text { consumption (\%) }\end{array}$ & $\begin{array}{l}\text { Sale } \\
(\%)\end{array}$ & $\begin{array}{l}\text { Village } \\
\text { activities (\%) }\end{array}$ \\
\hline Foods & & & \\
Wild animals & 90 & 10 & 0 \\
Honey & 12 & 88 & 0 \\
Fruit & 80 & 20 & 0 \\
Vegetables & 92 & 8 & 0 \\
Mushroom & 90 & 10 & 0 \\
Bamboo shoots & 48 & 52 & 0 \\
Fish & 86 & 14 & 0 \\
Materials & & & \\
Traditional hat materials & 10 & 90 & 0 \\
Medicinal plants & 60 & 40 & 0 \\
Roof covering materials & 97 & 0 & 3 \\
Rattan & 10 & 90 & 0 \\
Broom materials & 90 & 10 & 0 \\
Wood & 80 & 0 & 20 \\
Firewood & 96 & 3 & 1 \\
Water resources & 100 & 0 & 0 \\
\hline
\end{tabular}

Vietnamese hat materials (10\%), were also used for family consumption (Table 5). The percentage consumption of collected wood, roof covering materials, and firewood for community activities were $20 \%, 3 \%$, and $1 \%$, respectively.

\section{Spatial Characteristics of Ecosystem Service Collection}

In the forestland, 84\% $(n=833)$ and $89 \%(n=1168)$ points were observed for foods and materials, respectively, of which the production forest was most popular (Table 6). The concentration of collection points was not influenced by resource abundance, but rather by legal regulation of the local community's access to the forests. Using the government criteria of forest classification, the special-use forest covering the park has the most resource abundance among the three forest types, followed by the protection forest, with the lowest resource abundance in the production forest (Decision No.62, 2005, Decision No.61, 2005, Circular No.34, 2009). With regard to the governance, forest resources and forestland are under government management through state forest organizations. Administratively, the national park management board is responsible for the management of Bach Ma National Park, and the district and commune people's committees and state forest enterprises are responsible for the management of the forests located in the buffer zones. The local communities' access to these forests has been limited by different restriction levels placed on them (the most restrictive in the special-use forest, and the least restrictive in the production forest) (Decree No. 117, 2010, Decision No. 17, 2015, Decision No. 49, 2016). The number of collection points for water resources was equivalent in the forests and farmlands ( $n=$ 101 and 107, respectively). In addition, the number of collection points was highest in the mountainous districts, and Dong Giang district showed the highest number of points for collection of foods, materials, and water resources at 53\% $(n=525)$, $51 \%(n=667)$, and $48 \%(n=100)$, respectively.

With regard to terrain conditions, around $60 \%$ of collection points ( $n=587$ for foods, $n=752$ for materials, and $n=139$ for water resources) were located in hilly areas (altitudes from 100 to $500 \mathrm{~m}$ ), and the majority of food and material collection points were on flatter slopes (from 8 to 15 degrees) and undulating slopes (from 15 to 25 degrees). Also, our results indicated that the number of collection points for foods and materials decreased at a distance of over $4 \mathrm{~km}$ from the village centers, and increased at a distance of $6 \mathrm{~km}$ from the main roads. The measurements showed that most water collection points were within a distance of $2 \mathrm{~km}$ from village centers and main roads.

The densities of ecosystem service collection points were calculated over $1 \mathrm{~km}^{2}$ grids (Fig. 4). The frequency levels of collection were evaluated as "high" (13-19 points for foods, 24-35 points for materials and water resources), "medium" (7-13 points for foods, 13-24 points for materials and water resources), and "low" (0-7 points for foods and 0-13 points for materials and water resources). The results showed that "high" collection levels were observed at three locations for foods, one location for materials, and one location for water resources (Fig. 4).

The "high" collection level for foods and materials was mainly observed in the production forest while the "high" level of water resources was seen in the farmland. The densities of collection at "medium" and "low" levels were spread largely in the special-use forest and farmland, with their main concentration in the forests (Figs. 3a and 4). Some previous studies have indicated that poor households living near the forests often depend strongly on the forest ecosystem services (Mamo et al. 2007; van Noordwijk 2017). In this study, "high" collection levels for all ecosystem services were observed only in the mountainous districts where participants in participatory mapping exercise were Cotu (Figs. 3b and 4).

The "high" collection level for foods was mainly in the area of altitudes from 100 to $500 \mathrm{~m}$ and slopes from 25 to 45 degrees (Figs. 3c, d and 4), which is equivalent to the classification of hilly and steep terrain (Rahayuningsih et al. 2016). The collection level for materials was located in high hills and undulating terrain (altitudes from 500 to $1000 \mathrm{~m}$, and slopes from 15 to 25 degrees), and lowland and rather flat terrain (altitudes from 15 to $100 \mathrm{~m}$ and slopes from 0 to 8 degrees) for water resources (Figs. 3c, d and 4).

Delgado-Aguilar et al. (2017) noted that the high density of ecosystem service collection is often located close to main roads, and we also found that proximity to village centers influences the distribution. The "high" collection level for water resources was located within a distance of $2 \mathrm{~km}$ from village centers, and the collection level for materials was within $2-4 \mathrm{~km}$ from village 
Table 6 Number of ecosystem service collection points by land use, administrative units, terrain conditions, proximity to village centers, and proximity to main roads

\begin{tabular}{|c|c|c|c|c|}
\hline \multirow[t]{2}{*}{ Factors } & \multirow[t]{2}{*}{ Area $\left(\mathrm{km}^{2}\right)$} & \multicolumn{3}{|c|}{ Number of collection points } \\
\hline & & $\begin{array}{l}\text { Food } \\
(n=991)\end{array}$ & $\begin{array}{l}\text { Material } \\
(n=1316)\end{array}$ & $\begin{array}{l}\text { Water resources } \\
(n=208)\end{array}$ \\
\hline \multicolumn{5}{|l|}{ Land use } \\
\hline \multicolumn{5}{|l|}{ Forest land } \\
\hline Special-use & 418.20 & 196 & 439 & 6 \\
\hline Protection & 149.12 & 315 & 284 & 18 \\
\hline Production & 239.13 & 322 & 445 & 77 \\
\hline Farmland & 147.32 & 150 & 148 & 107 \\
\hline Others & 4.25 & 8 & 0 & 0 \\
\hline \multicolumn{5}{|l|}{ Administrative units } \\
\hline \multicolumn{5}{|l|}{ Mountainous districts } \\
\hline Dong Giang & 302.44 & 525 & 667 & 100 \\
\hline Nam Dong & 420.49 & 362 & 443 & 95 \\
\hline \multicolumn{5}{|l|}{ Plain district } \\
\hline Phu Loc & 235.00 & 104 & 206 & 13 \\
\hline \multicolumn{5}{|l|}{ Altitude (m) } \\
\hline 15-100 (lowland) & 145.99 & 78 & 59 & 35 \\
\hline $100-500$ (hill) & 433.99 & 587 & 752 & 139 \\
\hline 500-1000 (high hill) & 319.99 & 307 & 493 & 34 \\
\hline 1000-2000 (mountain) & 53.00 & 19 & 12 & 0 \\
\hline >2000 (high mountain) & 1.00 & 0 & 0 & 0 \\
\hline \multicolumn{5}{|l|}{ Slope (degree) } \\
\hline 0-8 (flat/level) & 164.99 & 132 & 144 & 23 \\
\hline $8-15$ (rather flat) & 282.00 & 283 & 411 & 69 \\
\hline 15-25 (undulating) & 285.99 & 324 & 429 & 78 \\
\hline $25-45$ (steep) & 208.00 & 242 & 322 & 38 \\
\hline$>45$ (very steep) & 13.00 & 10 & 10 & 0 \\
\hline \multicolumn{5}{|c|}{ Proximity to village centers (m) } \\
\hline$<2000$ & - & 145 & 252 & 107 \\
\hline $2000-4000$ & - & 348 & 506 & 77 \\
\hline $4000-6000$ & - & 284 & 312 & 24 \\
\hline $6000-8000$ & - & 190 & 156 & 0 \\
\hline$>8000$ & - & 24 & 90 & 0 \\
\hline \multicolumn{5}{|c|}{ Proximity to main roads (m) } \\
\hline$<2000$ & - & 200 & 215 & 148 \\
\hline $2000-4000$ & - & 216 & 283 & 37 \\
\hline $4000-6000$ & - & 227 & 406 & 9 \\
\hline $6000-8000$ & - & 202 & 200 & 12 \\
\hline$>8000$ & - & 146 & 212 & 2 \\
\hline
\end{tabular}

centers. The "high" collection level for foods occurred at distances of up to $6 \mathrm{~km}$ from village centers (Figs. 3e and 4).

\section{Conclusions}

Previous studies have indicated that the dependence of local communities on forest resources is the root cause of biodiversity loss in protected areas of Vietnam (De Queiroz et al.
2013). However, empirical data for specific types of ecosystem services, their distributions, and the number of dependent communities are limited. This study, conducted in the Bach Ma National Park and its buffer zones, attempts to fill these information gaps. Our results indicate that the poor ethnic minority communities living in the mountainous districts are highly dependent on multiple forest ecosystem services originating from different types of forestlands. As a consequence, the forest ecosystem may face ecological imbalance due to 

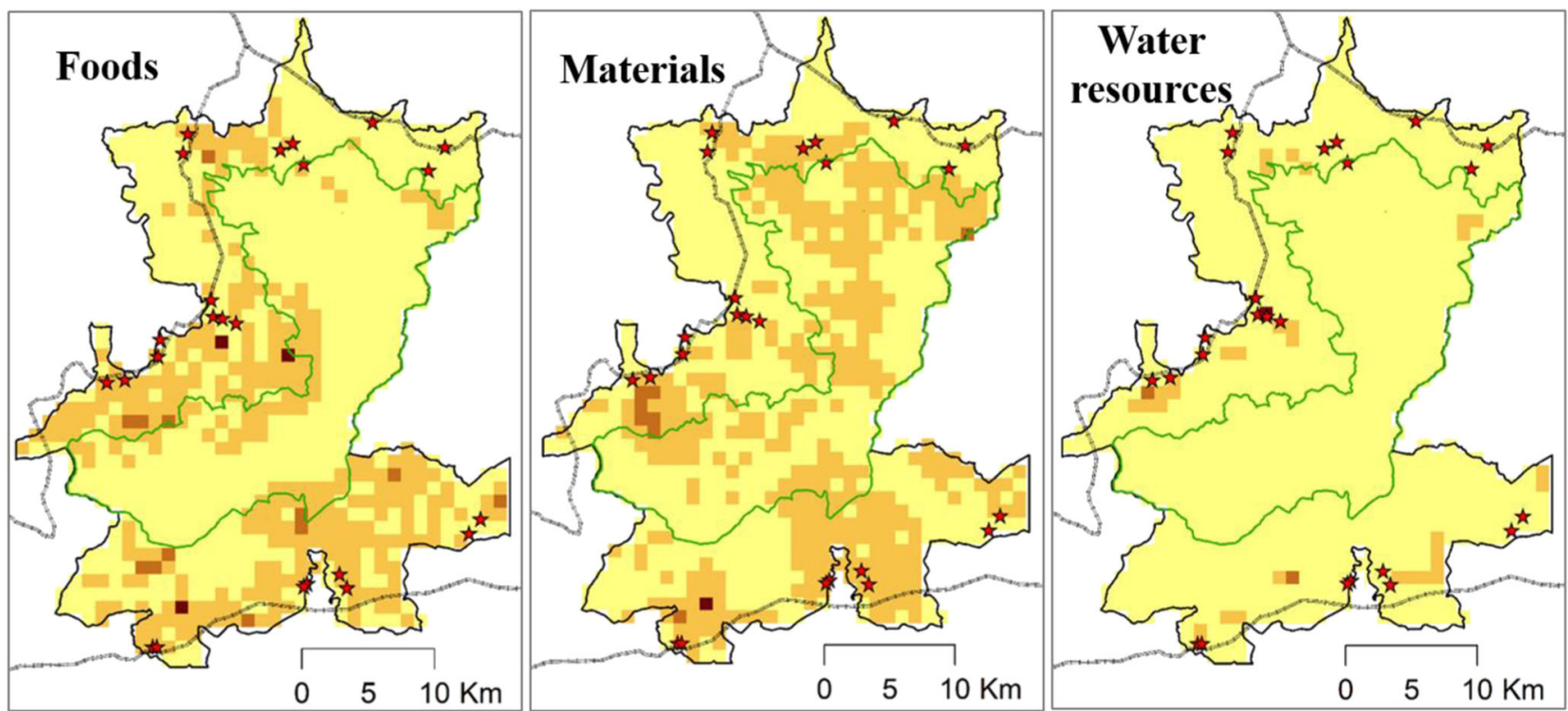

Frequency levels of collection:

None Low $\square$ Medium $\boldsymbol{n}$ High

Bach Ma National Park boundary

- Main roads

Fig. 4 Maps showing spatial distributions of frequency levels of collection of ecosystem services

slow regeneration of long-lived species and colonization by invasive species (Fredericksen and Mostacedo 2000; Sunderland et al. 2011, Muler et al. 2014). Cummings and Read (2016) concluded that intensive collection of one forest ecosystem service caused substantial declines in other services. For example, logging of trees may result in habitat loss for wildlife and fires used by the Cotu to smoke out bees during traditional collection of honey may cause forest fires. Therefore, in the light of the forest dependence of local communities, it is difficult for the forest management organizations to achieve sustainable management. We propose that investment in local livelihood options for the ethnic minorities would reduce their dependence on the forest resources and thus facilitate sustainable forest management.

Previous studies have proposed that development of agriculture or agroforestry could both enhance rural areas and reduce forest dependence (Kamanga et al. 2009; Teshome et al. 2015; Hlaing et al. 2017). A study conducted by Chung et al. (2015) in Nam Dong district indicated that agricultural activities on household-scale farmlands relied entirely on weather conditions and the lack of irrigation water in the dry season was a significant challenge in the highland areas of central Vietnam. This could be addressed by agricultural and agroforestry development at the household-scale in this area and would contribute to alleviating poverty in the Cotu communities. Meanwhile, utilization of regional resources, such as natural landscapes and local culture, in developing community-based ecotourism (CBT) (Masud et al. 2017) have been documented in the study area. The mountainous districts are located in the transition zone of northern (Sino-
Himalayan, Indo-Burmese) and southern (Malesian) floras, assessed as an important "Floristic Biodiversity Centre" for the Indochina region (Tran and Ziegler 2001). In addition, these districts are located inside the original area occupied by the minority Cotu with their distinct culture (Tran 2009).

CBT has been shown to be a "win-win" component in designing conservation strategies and improving livelihoods of poor communities (Barzekar et al. 2011; Kiper 2013). Socioeconomic benefits from CBT, such as employment and income generation for local communities, and contributions to conserving natural resources, have been examined in Nepal (Lama 2000), Tanzania (Nelson 2003), Botswana (Mbaiwa 2005), Uganda (Ahebwa 2013), Cambodia (Toko 2016), and Malaysia (Goh 2017). Thus, CBT appears to be a possible solution to reduce the dependence of local communities on forest ecosystem services in mountainous areas. In this regard, households significantly dependent on forest ecosystem services should be involved as the main stakeholders in new and alternative livelihood options. The success of CBT may be limited by a local lack of entrepreneurial and managerial experience. Therefore, investment in training local personnel in tourism skills should be a priority. For example, men in the age group of 38-49 years, who were significant participants in the meetings, could become the main stakeholders for naturebased tourism activities and trained in forest protection and managerial skills.

Karacaoglu (2017) defined 16 success factors of CBT that can be summarized into three groups: (1) community participation, (2) proximity to tourism markets and competitive advantages, and (3) tourist satisfaction and the quality of tourist services. 
There is a potential for CBT in the study area. A survey was conducted through group discussion with 30 local managers in six villages, and in-depth interviews with 158 local people in Dong Giang district, where the highest number of collection points was identified (Table 6). The local communities are well aware of limitations of legal barriers on maintaining their forestdependent livelihoods, and all respondents welcomed the prospect of new livelihood opportunities and confirmed their expectation and willingness to become the main stakeholders for CBT development. This consensus in turn would facilitate the success of the tourism development plan. In addition, the location of study area is near to two famous tourist destinations in central Vietnam, Hue and Da Nang (Fig. 1). Hue tourism provides historical and heritage values (Nguyen and Cheung 2014). Da Nang is the third largest city of Vietnam, and has developed coastal tourism and modern services (Hildebrandt and Isaac 2015). The development of CBT in the study area incorporating both the natural environment and cultural values of the ethnic minority groups can provide competitive advantages in the tourism market.

Finally, our research indicates that the livelihoods of ethnic minorities living in the mountainous districts, especially in Dong Giang district, needs to be improved to significantly reduce impacts on ecosystem services. Based on the analysis of local conditions, we propose CBT as an alternate livelihood option, which is likely to not only enhance lives of the forest dependent communities, but also increase their awareness with regard to forest protection and preservation of cultural values. Presently, the process of investigating the local resources of CBT development and its main stakeholders is underway. Our findings from this study can also be used as a reliable reference in developing sustainable forest management and restoration strategies in Bach Ma National Park and its buffer zones.

Funding This research was supported by JSPS KAKENHI Grant Number 16H05660.

\section{Compliance with Ethical Standards}

Conflict of Interest The authors declare that they have no conflict of interest.

Open Access This article is distributed under the terms of the Creative Commons Attribution 4.0 International License (http:// creativecommons.org/licenses/by/4.0/), which permits unrestricted use, distribution, and reproduction in any medium, provided you give appropriate credit to the original author(s) and the source, provide a link to the Creative Commons license, and indicate if changes were made.

\section{References}

Ahebwa, W.M. (2013). Conservation, Livelihoods, and Tourism: A Case Study of the Buhoma-Mukono Community-Based Tourism Project in Uganda. Journal of Park and Recreation Administration 31.

Alcamo, J. (2003). Ecosystems and Human Well-Being: A Framework for Assessment, Island Press, Washington, DC.
Barzekar, G., Aziz, A., Mariapan, M., Ismail, M. H., and Hosseini, S. M. (2011). Delphi Technique for Generating Criteria and Indicators in Monitoring Ecotourism Sustainability in Northern Forests of Iran: Case study on Dohezar and Sehezar Watersheds. Folia Forestalia Polonica Series A 53: 130-141. https://doi.org/10.5281/zenodo.30611.

Brown, G. (2004). Mapping Spatial Attributes in Survey Research for Natural Resource Management: Methods and Applications. Society and Natural Resources 18: 17-39.

Bryan, B. A., Raymond, C. M., Crossman, N. D., and Macdonald, D. H. (2010). Targeting the management of ecosystem services based on social values: Where, what, and how? Landscape and Urban Planning 97: 111-122.

Chung, N.T., Jintrawet, A., Promburom, P. (2015). Impacts of Seasonal Climate Variability on Rice Production in the Central Highlands of Vietnam. Agric. Agric. Sci. Procedia, 1st International Conference on Asian Highland Natural Resources Management (AsiaHiLand) and 2nd IDRC-SEARCA Upland Fellowship and Conference Chiang Mai, Thailand January 7-9, 2015 5, 83-88. https://doi.org/ 10.1016/j.aaspro.2015.08.012

(Circular No.34, 2009) Ministry of Agriculture and Rural Development, 2009. Circular No.34/2009/TT-BNNPTNT on criteria for forest identification and classification.

Coulibaly-Lingani, P., Tigabu, M., Savadogo, P., Oden, P.-C., and Ouadba, J.-M. (2009). Determinants of Access to Forest Products in Southern Burkina Faso. Forest Policy and Economics 11: 516524. https://doi.org/10.1016/j.forpol.2009.06.002.

Cummings, A. R., and Read, J. M. (2016). Drawing on Traditional Knowledge to Identify and Describe Ecosystem Services Associated with Northern Amazon's Multiple-Use Plants. International Journal of Biodiversity Science Ecosystem Services Management 12: 39-56.

De Queiroz, J. S., Griswold, D., Nguyen, D. T., and Hall, P. (2013). Vietnam Tropical Forest and Biodiversity Assessment, USAID Vietnam.

(Decision No. 17) The Vietnam Government (2015). Decision No. 17/ 2015/QD-TTg regulation on protective forest management.

(Decision No. 49) The Vietnam Government (2016). Decision 49/2016/ QD-TTg Regulation production forest management.

(Decision No. 73) The Vietnamese Committee for Ethnic Minority Affairs (2016). Decision No. 73/QD-UBDT on February 29th, 2016 about adjusting wards in area I, II, III in the mountainous and minority ethnic groups' areas.

(Decision No. 447) The Vietnamese Committee for Ethnic Minority Affairs (2013). Decision No. 447 / QD-UBDT on September 19th, 2013 of the Committee for Ethnic Minority Affairs recognizing villages meeting with special difficulties, communes in regions I, II and III in ethnic minority and mountainous areas in the 2012-2015 period.

(Decision No. 601) The Vietnamese Committee for Ethnic Minority Affairss (2015). Decision No. 601/QD-UBDT on October 29th, 2015 about recognizing the addition, adjustment of under poverty hamlets, wards in area I, II, III in the mountainous and minority ethnic groups' areas.

Decision No.61 (2005). Ministry of Agriculture and Rural Development, 2005. In Decision No.61/2005/QD-BNN promulgating the regulation on protection forest classification criteria.

(Desision No. 62) Ministry of Agriculture and Rural Development (2005). Decision No. In 62/2005/QD-BNN promulgating the regulation on criteria for classification ò special-use forest.

(Decree No. 117) The Vietnam Government (2010). Decree no. 117/ 2010/ND-CP on the organization and management of the specialuse forest system.

Delgado-Aguilar, M. J., Konold, W., and Schmitt, C. B. (2017). Community Mapping of Ecosystem Services in Tropical Rainforest of Ecuador. Ecological Indicators 73: 460-471. https://doi.org/10.1016/j.ecolind. 2016.10.020.

Fredericksen, T. S., and Mostacedo, B. (2000). Regeneration of Timber Species Following Selection Logging in a Bolivian Tropical 
Dry Forest. Forest Ecology and Management 131: 47-55. https://doi.org/10.1016/S0378-1127(99)00199-1.

Gilmour, D. A., and Nguyen, V. S. (1999). Buffer zone Management in Vietnam, IUCN For. Prot. Dep. Hanoi.

Goh, H.C. (2017). Nature and Community-Based Tourism (CBT) for Poverty Alleviation: A Case Study of Lower Kinabatangan, East Malaysia. Geografia - Malaysian Journal of Society and Space 11.

Hlaing, Z. C., Kamiyama, C., and Saito, O. (2017). Interaction Between Rural People's Basic Needs and Forest Products: A Case Study of the Katha District of Myanmar. International Journal of Forestry Research 2017.

Hildebrandt, T. and Isaac, R. (2015). The tourism structures in central Vietnam: Towards a destination management organisation. Tourism Planning \& Development 12(4): 463-478.

Huynh, H. T. N., Bruyn Lobry de, L., Prior, J., and Kristiansen, P. (2016). Community Participation and Harvesting of Non-Timber Forest Products in Benefit-Sharing Pilot Scheme in Bach Ma National Park, Central Vietnam. Tropical ConservAtion Science 9: 877-902.

Kamanga, P., Vedeld, P., and Sjaastad, E. (2009). Forest incomes and rural livelihoods in Chiradzulu District, Malawi. Ecological Economics 68: 613-624. https://doi.org/10.1016/j.ecolecon.2008.08.018.

Karacaoglu, S., and Birdir, K. (2017). Success Factors of Community Based Tourism (CBT) Perceived by Local Peoples: The Case of \% 100 Misia Project. International Rural Tourism and Development Journal 1(2): 53-61.

Kim, L. T. T., Nichols, J. D., and Brown, K. (2017). Firewood Extraction and Use in Rural Vietnam: A Household Model for Three Communes in Ha Tinh Province. Agroforestry Systems 91: 649 661. https://doi.org/10.1007/s10457-016-9993-0.

Kiper, T. (2013). Role of Ecotourism in Sustainable Development. Advances Landscape Architecture. https://doi.org/10.5772/55749.

Lakerveld, R. P., Lele, S., Crane, T. A., Fortuin, K. P. J., and SpringateBaginski, O. (2015). The social Distribution of Provisioning Forest Ecosystem Services: Evidence and Insights from Odisha, India. Ecosystem Services 14: 56-66.

Lama, W. B. (2000). Community-based tourism for conservation and women's development. In Godde, P. M., Price, M. F., and Zimmermann, F. M. (eds.), Tourism and development in mountain regions. CABI Publishing, Wallingford, pp. 221-238.

Langat, D. K., Maranga, E. K., Aboud, A. A., and Cheboiwo, J. K. (2016). Role of Forest Resources to Local Livelihoods: The Case of East Mau Forest Ecosystem, Kenya. International Journal of Forestry Research 2016.

López-Feldman, A., and Wilen, J. E. (2008). Poverty and Spatial Dimensions of Non-Timber Forest Extraction. Environment and Development Economics 13: 621-642.

Mamo, G., Sjaastad, E., and Vedeld, P. (2007). Economic Dependence on Forest Resources: A Case from Dendi District, Ethiopia. Forest Policy and Economics 9: 916-927. https://doi.org/10.1016/j.forpol. 2006.08.001.

Masud, M. M., Aldakhil, A. M., Nassani, A. A., and Azam, M. N. (2017). Community-Based Ecotourism Management for Sustainable Development of Marine Protected Areas in Malaysia. Ocean and Coastal Management 136: 104-112. https://doi.org/10.1016/j. ocecoaman.2016.11.023.

Mbaiwa, J.E. (2005). Community-based tourism and the marginalized communities in Botswana: The case of the Basarwa in the Okavango Delta, in: Indigenous Tourism. pp. 87-109.

McNeely, J. A. (1994). Protected Areas for the 21st Century: Working To Provide Benefits to Society. Biodiversity and Conservation 3: 390-405.

Muler, A. E., Rother, D. C., Brancalion, P. S., Naves, R. P., Rodrigues, R. R., and Pizo, M. A. (2014). Can Overharvesting of a Non-Timber-ForestProduct Change the Regeneration Dynamics of a Tropical Rainforest? The Case Study of Euterpe Edulis. Forest Ecology and Management 324: 117-125. https://doi.org/10.1016/j.foreco.2013.09.001.
Nelson, F. (2003) Community-Based Tourism in Northern Tanzania: Increasing Opportunities, Escalating Conflicts and an Uncertain Future. Rozenberg Publishers.

Nguyen, T. H. H., and Cheung, C. (2014). The Classification of Heritage Tourists: A case of Hue City, Vietnam. Journal of Heritage Tourism 9: $35-50$

Palomo, I., Martín-López, B., Potschin, M., Haines-Young, R., and Montes, C. (2013). National Parks, Buffer Zones and Surrounding Lands: Mapping Ecosystem Service Flows. Ecosystem Services 4: 104-116.

Phan, T.T. (2015). Research on Biodiversity of Butterflies (Lepidoptera: Rhopalocera) in Bach Ma National Park, Vietnam. Hue University Journal of Science HU JOS 98.

Pilgrim, J. D., and Tu, N. D. (2007). Background paper on threatened and alien species in Vietnam and recommendations for the content of the Biodiversity Law. Report to the Department of Environment, Ministry of Natural Resources and Environment. Hanoi: BirdLife International Vietnam Programme.

Plant, R. (2002). Indigenous Peoples/Ethnic Minorities and Poverty Reduction: Regional Report. Asian Development Bank. http://hdl. handle.net/11540/2968. Accessed 7 Feb 2018

Rahayuningsih, T., Muntasib, E. H., and Prasetyo, L. B. (2016). Nature Based Tourism Resources Assessment Using Geographic Information System (GIS): Case Study in Bogor. Procedia Environmental Sciences 33: 365-375.

Ramage, M. H., Burridge, H., Busse-Wicher, M., Fereday, G., Reynolds, T., Shah, D. U., Wu, G., Yu, L., Fleming, P., Densley-Tingley, D., Allwood, J., Dupree, P., Linden, P. F., and Scherman, O. (2017). The Wood from the Trees: The Use of Timber in Construction. Renewable and Sustainable Energy Reviews 68: 333-359. https://doi.org/10.1016/j.rser.2016.09.107.

Ramirez-Gomez, S. O., Torres-Vitolas, C. A., Schreckenberg, K., Honzák, M., Cruz-Garcia, G. S., Willcock, S., Palacios, E., Pérez-Miñana, E., Verweij, P. A., and Poppy, G. M. (2015). Analysis of Ecosystem Services Provision in the Colombian Amazon Using Participatory Research and Mapping Techniques. Ecosystem Services 13: 93-107.

Sakai, S., Choy, Y. K., Kishimoto-Yamada, K., Takano, K. T., Ichikawa, M., Samejima, H., Kato, Y., Soda, R., Ushio, M., Saizen, I., Nakashizuka, T., and Itioka, T. (2016). Social and ecological factors associated with the use of non-timber forest products by people in rural Borneo. Biological Conservation 204: 340 349. https://doi.org/10.1016/j.biocon.2016.10.022.

Shackleton, C. M., Sheona, E., and Cousins, B. (2001). The Role Of LandBased Strategies in Rural Livelihoods: The Contribution of Arable Production, Animal Husbandry and Natural Resource Harvesting in Communal Areas in South Africa. Development Southern Africa 18: 581-604. https://doi.org/10.1080/03768350120097441.

Spelchan, D. G., Nicoll, I. A., and Nguyen, T. P. H. (2011). Co-management/Shared Governance of Natural Resources and Protected Areas in Viet Nam. Vietnam: Deutsche Gesellschaft für Internationale Zusammenarbeit (GIZ).

Struhsaker, T. T., Struhsaker, P. J., and Siex, K. S. (2005). Conserving Africa's Rain Forests: Problems in Protected Areas and Possible Solutions. Biological Conservation 123: 45-54.

Sunderland, T., Achdiawan, R., Angelsen, A., Babigumira, R., Ickowitz, A., Paumgarten, F., Reyes-García, V., and Shively, G. (2014). Challenging Perceptions about Men, Women, and Forest Product Use: A Global Comparative Study. World Development, Forests, Livelihoods, and Conservation 64: S56-S66. https://doi.org/10. 1016/j.worlddev.2014.03.003.

Sunderland, T. C., Ndoye, O., and Harrison-Sanchez, S. (2011). Nontimber forest products and conservation: What prospects? In NonTimber Forest Products in the Global Context, Springer, pp. 209-224.

Teshome, B., Kassa, H., Mohammed, Z., and Padoch, C. (2015). Contribution of Dry Forest Products to Household Income and 
Determinants of Forest Income Levels in the Northwestern and Southern Lowlands of Ethiopia. Natural Resources 6: 331.

Toko, A. (2016). Community-Based Ecotourism as a Tool for Conservation: A Case from Cambodia. Journal of Environment Information Science 44: 149-156.

Tran, T. A., and Ziegler, S. (2001). Utilization of medicinal plants in Bach Ma National Park, Vietnam. Medical Plant Conservation 7: 3-5.

Tran, T.V. (2009). The Cotu in Vietnam. VNA Publishing House, Ha Noi, Vietnam.

van Noordwijk, M. (2017). Integrated Natural Resource Management as Pathway to Poverty Reduction: Innovating Practices, Institutions and Policies. Agricultural Systems.

Van, T. Y., Nguyen, H. K. L., Nguyen, B. N., and Le, Q. T. (2016). Study on Biomass and Carbon Stock of Woody Floor at Several Forests in
Bach Ma National Park, Thua Thien Hue province. Journal of Vietnamese Environment 8: 88-94.

Vihervaara, P., Marjokorpi, A., Kumpula, T., Walls, M., and Kamppinen, M. (2012). Ecosystem Services Of Fast-Growing Tree Plantations: A case Study on Integrating Social Valuations with Land-Use Changes in Uruguay. Forest Policy and Economics 14: 58-68.

Webb, E. L., and Honda, K. (2007). Biophysical and Policy Drivers of Landscape Change in a Central Vietnamese District. Environmental Conservation 34: 164-172.

Publisher's Note Springer Nature remains neutral with regard to jurisdictional claims in published maps and institutional affiliations. 